\title{
The Effect of Bridge Piers on Local Scouring at Alue Buloh Bridge Nagan Raya Regency
}

\author{
Cut Suciatina Silvia*, Muhammad Ikhsan, Azwanda \\ Department of Civil Engineering, Teuku Umar University, INDONESIA \\ Jalan Alue Peunyareng, Meulaboh \\ *Corresponding authors: coetsilvia@utu.ac.id
}

SUBMITTED 9 July 2020 REVISED 28 August 2020 ACCEPTED 21 September 2020

\begin{abstract}
Scouring that occurs in cross-section a river can be caused by morphological conditions of the river and the effect of bridge piers that obstruct the flow. Availability of piers and abutments can cause the stability of soil base granules to be disrupted, downflow, and horseshoe vortex that causes soil base granules around the bridge pier to be transported the flow that causes occurrence in local scouring. The problems of local scours also occurred in Krueng Ineng river, Alue Buloh Village, Nagan Raya Regency. The problem that is often encountered due to bridges being built across rivers is the lack of functioning of the under-bridge structures. Local scours on the bridge piers will cause a structural collapse which has the impact of decreasing the stability of the bridge structure currently. In this study, local scour analysis are using empirical equations with the Froehlich, Lacey and Colorado State University Method. The Results of the analysis with used the peak discharge $\left(\mathrm{Qp}_{100}\right)$ that occurs in the Krueng Seunagan watershed is $1513 \mathrm{~m}^{3} / \mathrm{sec}$. Analysis with a flow depth of $3.06 \mathrm{~m}$, Froude number 0.29 , pier width with lenticular shaped $4 \mathrm{~m}$, and D50, D95 (average grain size analysis ) $0.91 \mathrm{~mm}$ and $4.35 \mathrm{~mm}$, show a maximum scour depth at the field of $1.65 \mathrm{~m}$ and $1.68 \mathrm{~m}$ occurs in point (station) 2 and 3 on segment 5. Analysis with the Froehlich, Lacey Method and the CSU Method shows a scour depth is $1.68 \mathrm{~m}, 4,47 \mathrm{~m}(\mathrm{Qp} 100)$ and $2.43 \mathrm{~m}$. The closest measurement result in the field is the Froehlich Method. With this result, it might be input for local governments to plan appropriate handling for minimizing local scour in this study area.
\end{abstract}

KEYWORDS Local Scour; Scour Depth; Lacey Method; Froehlich Method; CSU Method.

(C) The Author(s) 2021. This article is distributed under a Creative Commons Attribution-ShareAlike 4.0 International license.

\section{INTRODUCTION}

The problem experienced by bridges on the crosssection of a river is the damage to the structures underneath such as the foundations, piers, and abutments, and this, in some cases, usually leads to the collapse of the bridges. The main structure at the bottom of the bridge is piers and is directly related to the water flowing in the river which is mostly accompanied by scouring and sedimentation processes. It has, however, been reported that scouring is mainly caused by river morphological conditions and the existence of piers obstructing the flow of water (Rizaldi et al. 2020).

The existence of obstacles such as the structure under the bridge has the ability to change the river morphology and cause aggradation and degradation. Riverbed aggradation makes the river to experience sedimentation and the settling of the sediments usually leads to flooding due to the reduction in the river basin. Moreover, the sediments constantly eroded based on the increased flow velocity causes instability in the bridge structure above. Meanwhile, degradation deepens the riverbed erosion and the occurrence of this erosion on the cliffs widens the river and causes meander deposition (Purwantoro 2015). Local scouring usually occurs in a river channel obstructed by a bridge pier and this normally leads to a vortex at the upstream bridge of the piers which changes the water flow rapidly and this acceleration raises the water level (Ahmad et al. 2017).

The horizontal angle of attack due to bridge piers and abutments is also able to cause a disrupted material balance on the riverbed, establishment of downflow, and horseshoes vortex which further leads to the transportation of the riverbed around the piers by the water flow, thereby, leading to 
local scouring. This, however, affects the structural stability of the bridge (Breusers and Raudkivi 1991). Meanwhile, the formation of a vortex at the base of the pier due to obstruction is known as horseshoes vortex (Akan 2006).

Scouring occurs due to sedimentation, narrowing of river flow, and local scouring, and its analysis is very complicated due to the influence of the river conditions and geometry which also cause bridge stability problems. Moreover, scouring by contraction is associated with the continuously narrow morphology of rivers which is mostly caused by the existence of water buildings (Rustiati 2007). Several factors have been reported to be affecting scouring and one of these is the shape of the pier which affects the flow pattern around the bridge pier and influences the creation and strength of the vortex (Farooq and Ghumman 2019). The maximum scours depth of a rectangular pier has been reported to be $6.3 \mathrm{~cm}$ while the minimum is $2.6 \mathrm{~cm}$ and the increment in the value was associated with the increased intensity of flow parameters. Furthermore, the rectangular shape is considered the best among the three types of piers restricting the local scour due to its 50\% maximum scouring (Roy 2017).

The correlation between scour depth and other parameters is used to represent the flood flow, bottom sediment characteristics, river geometry, and scour rate (Melville 2008). Several experimental and theoretical studies have been conducted on scouring using several parameters and the three types observed to be due to the influence of bridge pier are general, local, and contraction scour. Moreover, some of the factors discovered to be affecting scour depth around bridge pier include river flow velocity, flow depth, sediment roughness as well as pier size and shape (Piers, Akib, and Rahman 2013). Meanwhile, Colorado State University (CSU) method is the most widely used equation to predict the maximum scour depth for live-bed conditions and clear water conditions in America (Administration 2012).

Local scouring is observed at the riverbed around the Alue Buloh- Latong bridge which provides access between two villages. Therefore, this study aimed to determine the magnitude of design flow discharge in the rivers for 50 and 100 years after which the data obtained were used to predict the scour depth around the bridge pier. Moreover, the scour depth was analyzed using empirical methods including Froehlich, Lacey, and the Colorado State University (CSU) methods. The findings are expected to be useful for the Regional Government in handling local scour in the study location.

\section{METHODS}

\subsection{Location Research}

The research was conducted only in areas experiencing local scouring problems under the bridge in Alue Buloh area of Seunagan District, Nagan Raya Regency which provides access between Alue Buloh and Latong Villages as shown in Figure 1.

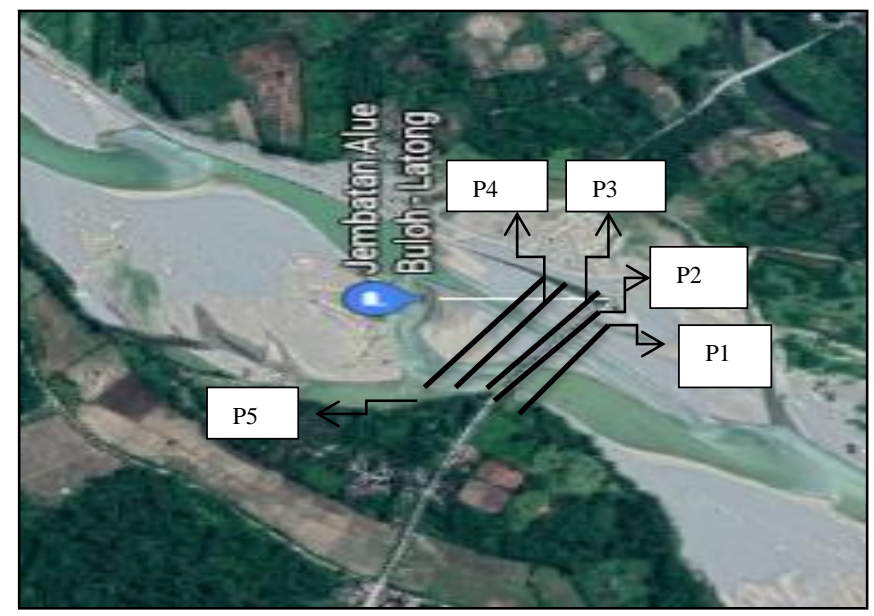

Figure 1. Location of Study In Alue Buloh

\subsection{Procedures and Analysis}

Primary data were obtained through observation in the field while secondary data were retrieved from related institutions to support the research. The primary data include the shape and dimensions of the pier, the distance between the piers, pier length, depth of flow, the angle of attack of flow, and sediment samples while the secondary ones were in the form of a topographic map, river cross-section, and rain data obtain the design of flood discharge. 
The methodology was arranged to simplify the research implementation as indicated in Figure 2 and the data were processed using the following flowchart.

1. Field survey

2. Field data retrieval including pier dimensions, pier shapes, sediment samples, depth of flow, the velocity of flow, and riverbed elevation. The data were measured between January April 2020 and a uniform type of flow was used.

3. Water flow velocity in the rivers was measured with a buoy due to the unavailability of the current meter:

a. One point was set on the side of the river with a wooden peg and another point was marked perpendicular to the direction of flow across the river

b. The distance L 20 meters perpendicular to the flow was determined

c. The buoy was washed by pressing the stopwatch button at the start

d. The stopwatch was pressed again when the buoy crossed the second line to determine the $\mathrm{T}$ flow time

e. Flow velocity was calculated using the length of the distance divided by time or $\mathrm{L} /$ $\mathrm{T}(\mathrm{m} / \mathrm{sec})$. It is important to note that this method was used to obtain the flow velocity at the surface only, and needed to be measured several times due to the uneven distribution of surface flow.

4. Grain size analysis:

a. Sediment samples were obtained at 9 points including the left, middle, and right of the river at a quiet flow

b. The sediment samples were tested using a sieve analysis to determine the percentage of sediment that passed through the sieve

c. A filter analysis chart was provided to show the correlation between a sieve diameter and the percentage of sediment that escaped

d. The average grain size of $D_{50}$ and $D_{95}$ from the graph was used in the study.

5. River bed elevation measurement:

a. A point was specified in the upper part of the river as the datum point b. The river sta was divided into several directions and each was further divided into several segments with their respective distances

c. The base elevation in each segment was measured with theodolite and a crosssection of the river was drawn.

6. Analysis of the design flood discharge using the Synthetic Hydrograph Nakayasu method which was described by Soewarno (1995) to be a way of obtaining the flood hydrograph design in a watershed. Meanwhile, the parameters covering the watershed area were needed to determine the magnitude of the design flood hydrograph using the following Nakayasu Synthetic Unit Hydrograph Equation (Yuliansyah, Aprizal, and Nurhasanah 2017).

$Q p=\frac{1}{3.6}\left(\frac{A R e}{0.3 T p+T_{0.3}}\right)$

Where: $Q_{p}=$ design flood discharge $\left(\mathrm{m}^{3} / \mathrm{s}\right), \mathrm{Re}=$ unit rain $(\mathrm{mm}), T_{p}=$ time lag which is the beginning of the rain to the peak of the flood (hour), $T_{0.3}=$ time required for a decrease from peak discharge to $30 \%$ (hour).

$$
\begin{aligned}
& t_{g}=0.4+0.058 L \rightarrow \text { for } L>15 \mathrm{~km} \\
& T_{p}=T_{g}+0.8 T_{r} \\
& t_{g}=0.21 L^{0.7} \rightarrow \text { for } L<15 \mathrm{~km} \\
& T r=0.5 \mathrm{tg} \\
& T_{0.3}=\alpha \mathrm{tg}
\end{aligned}
$$

The synthetic unit hydrograph curve equation is as follows:

For $t<T p$ :

$$
Q t=Q p\left(\frac{t}{T p}\right)^{2.4}
$$

For $t<T p+T_{0.3}$ :

$$
Q t=Q p 0.3^{\wedge\left(t-T P / T_{0,3}\right)}
$$

For $t<T p+T_{0.3}+1.5 T_{0.3}$ :

$Q t=Q p 0.3^{\wedge}\left((t-T P)+\left(0,5 T_{0.3}\right) /\left(1,5 T_{0.3}\right)\right)$

for $t>T p+T_{0.3}+1,5 T_{0.3}$ :

$$
Q t=Q p 0.3^{\wedge}\left((t-T P)+\left(1.5 T_{0.3}\right) /\left(2 T_{0.3}\right)\right)
$$


Where $T_{r}=$ duration of effective rain, $T_{g}=$ concentration time (hour), $t=$ time (hour), $L=$ length of river channel $(\mathrm{km})$, and $Q_{t}=$ Runoff before and after reaching peak discharge $\left(\mathrm{m}^{3} / \mathrm{sec}\right)$.

7. The scour depth was determined using the CSU, Lacey, and Froehlich methods.

The CSU equation is the most widely used equation to predict the maximum of scour depths for both live-bed and clear-water scour conditions in America (Garde, $\mathrm{R}$ and Kothyari, U 1998).

$$
\begin{aligned}
& d_{s}=2.0 K_{1} K_{2} K_{3} K_{4} F^{0.43} y_{3}^{0.35} \\
& K_{2}=\left(\cos \theta \mathrm{p}+\frac{L}{b} \sin \theta p\right)^{0.65} \\
& K_{4}=0.4\left(V_{R}\right)^{0.15} \\
& V_{R}=\left(\frac{V_{3}-V_{i 50}}{V_{c 50}-V_{i 95}}\right. \\
& V_{c 50}=K_{u} y_{3}{ }^{1 / 6} D_{50}{ }^{1 / 3} \\
& V_{i 50}=0.645\left(\frac{D_{50}}{b}\right)^{0.053} V_{c 50} \\
& V_{i 95}=0.645\left(\frac{D_{95}}{b}\right)^{0.053} V_{c 95} \\
& V_{c 95}=K_{u} y_{3}{ }^{1 / 6} D_{95}{ }^{1 / 3}
\end{aligned}
$$

Where $d_{s}=$ scour depth (m), $K_{1}=$ correction factor for pier nose shape as shown in Table $1, K_{2}=$ correction factor for angle of attack of flow shown in Table $2, K_{3}=$ correction factor for bed condition shown in Table 3 , and $K_{4}=$ correction factor to amor bed material and was found to be 1.0 at $D_{50}$ $<2 \mathrm{~mm}$ or $D_{95}<20 \mathrm{~mm}$ and decreases the scour depths at $D_{50}>2 \mathrm{~mm}$ and $D_{95}>20 \mathrm{~mm}$ (Mueller and Jones, 1999), $V_{R}=$ velocity ratio, $V_{3}=$ average velocity at the main channel of the cross-section just upstream of the bridge, $V_{i 50}=$ approach velocity required to initiate scour at the pier for grain size $D_{50}, V_{i 95}=$ approach velocity required to initiate scour at the pier for grain size $D_{95}, V_{c 50}=$ critical velocity for $D_{50}$ bed material size, $V_{c 95}=$ critical velocity for $D_{95}$ bed material size, $K_{u}=6.19$ $\mathrm{m}^{1 / 2} / \mathrm{s}=11.17 \mathrm{ft}^{1 / 2} / \mathrm{s}$, and $y_{3}=$ depth of flow from upstream of the pier, $\mathrm{Fr}=$ Froude number, $y_{3}=$ flow depth directly upstream of pier $(\mathrm{m}), \theta_{p}=$ pier angle of an attack, $L=$ pier length $(\mathrm{m})$, and $b=$ pier width $(\mathrm{m})$.

Table 1. Correction Factors K1 For Pier Shape

\begin{tabular}{lll}
\hline No & Shape of pier nose & $K_{1}$ \\
\hline 1 & Square nose & 1.1 \\
2 & cylinder & 1.0 \\
3 & Round nose & 1.0 \\
4 & Circular cylinder & 1.0 \\
5 & Sharp nose & 0.9 \\
\hline
\end{tabular}

Table 2. Correction Factors K2 For Pier Angle

\begin{tabular}{lllll}
\hline No & pier angle & $L / b=4$ & $L / b=8$ & $L / b=12$ \\
\hline 1 & 0 & 1.0 & 1.0 & 1.0 \\
2 & 15 & 1.5 & 2.0 & 2.5 \\
3 & 30 & 2.0 & 2.75 & 3.5 \\
4 & 45 & 2.3 & 3.3 & 4.3 \\
5 & 90 & 2.5 & 3.9 & 5.0 \\
\hline
\end{tabular}

Several methods are used in calculating scour depth on the riverbed around the piers and some of them include Laursen and Toch, Lacey, Colorado State University Method (CSU), Breuser and Raudkivi, Simon, Senturk, and the Froehlich methods.

Table 3. Correction Factors K3 For Bad Condition

\begin{tabular}{lll}
\hline Bed condition & Dune height & $K_{3}$ \\
\hline Clearwater scour & Not applicable & 1.1 \\
Plane bed and antidune flow & Not applicable & 1.1 \\
Small dunes & $0.6-3.0 \mathrm{~m}$ & 1.1 \\
Medium dunes & $3.0-9.1 \mathrm{~m}$ & $1.1-1.2$ \\
Large dunes & $>9.1 \mathrm{~m}$ & 1.3 \\
\hline
\end{tabular}

The equation developed by Dr. David Froehlich (1987) showed the scour depth as a function of Froude number, pier width, flow angle of attack, pier type, and grain size (Froehlich 2013) and presented as follows: 
$d_{s}=0.32 b K\left(\frac{b^{\prime}}{b}\right)^{0,02}\left(\frac{y}{b}\right)^{0.46} F^{0,2}\left(\frac{b}{d_{50}}\right)^{0.08}+1.0$

$b^{\prime}=b \cos \beta+L \cdot \sin \beta$

Meanwhile, Chow (1988) showed the earth's attraction to flow is expressed by the ratio of inertia to the earth's attraction force $(\mathrm{g})$ as shown in the following relationship.

$F_{r}=\frac{V}{\sqrt{g h}}$

Where ds $=$ scour depth $(\mathrm{m}), F_{r}=$ Froude number, $y=$ depth of flow $(\mathrm{m}), b=$ width of the pier, $\Theta=$ flow angle, $L=$ length of pier (m), $d_{50}=$ grain size (m), $\mathrm{K}=$ coefficient of pier type which is 1.3 for square, 1.0 for round or round-ended, and 0.7 for acute-pointed, $V=$ flow velocity $(\mathrm{m} / \mathrm{s})$, and $h=$ depth of flow (m).

Lacey (1930) also introduced a formula to predict the maximum scour depth around piers and abutment-like structures as follows (Rahman and Haque 2003).

$d_{s}=0.47\left(\frac{Q}{f}\right)^{0.33}$

where $d_{s}=$ scour depth measured from the initial bed level, $h$ = approach flow depth, $Q=$ regime discharge, $f=$ Lacey clay factor which is a function of basic material $=1.76 \times \sqrt{ }$ (grain size) $d 50$, and $d 50=$ grain size diameter $(\mathrm{mm})$.

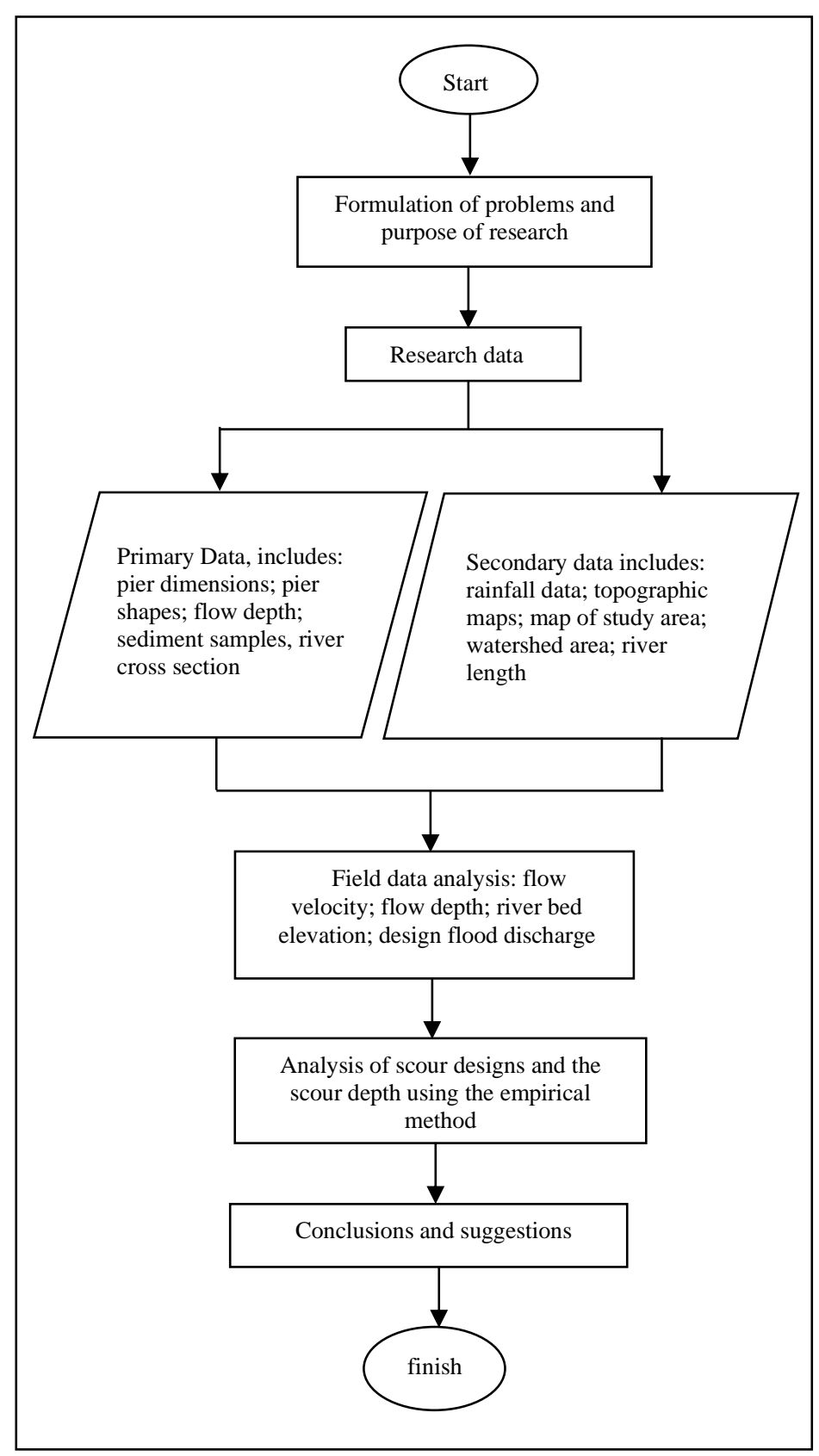

Figure 2. The Flowchart of Research Implementation 


\section{RESULTS AND DISCUSSION}

\subsection{Pier Dimension Measurement}

This was conducted to determine the dimensions of the piers used in this research and the data obtained on the width, the distance between piers, and shape from the field are presented in Table 4 while the map of the situation in the study area is indicated in Figure 3.

Table 4. Measurement of Pier Dimensions

\begin{tabular}{lll}
\hline No & Measurement of Pier Dimension & \\
\hline 1 & pier width & $4 \mathrm{~m}$ \\
2 & the distance between piers & $50 \mathrm{~m}$ \\
3 & pier shape & Round nose \\
\hline
\end{tabular}

\subsection{Measurement of Riverbed Elevation}

The data were used to obtain the river bed elevation measurements shown in the following Figure 3.

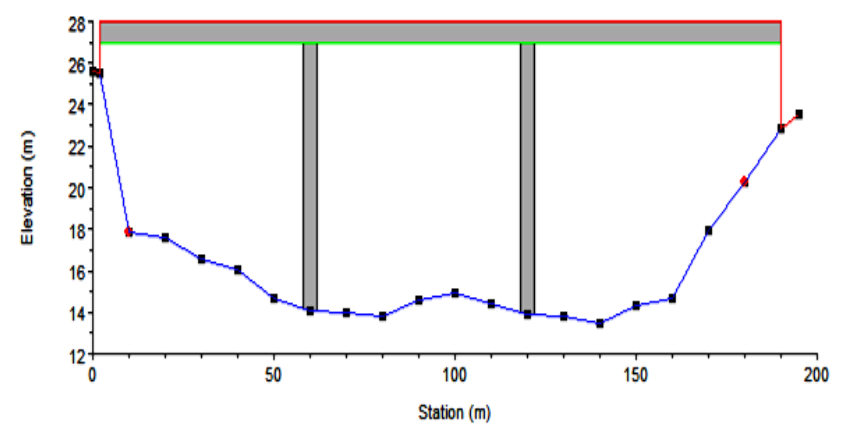

Figure 3. Cross-section of The Riverbed Elevation Data River Station

The grain size was analyzed to determine the diameter required as a parameter in scour depth calculation with the focus on the average particle size diameter of $\mathrm{D}_{50}$ and $\mathrm{D}_{95}$ sediment grain as presented in Figure 4 and Table 5.

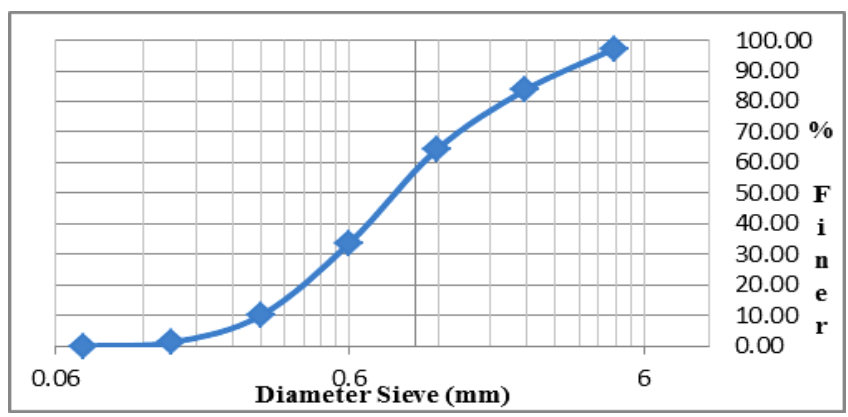

Figure 4. Sediment Grain Size Analysis
Table 5. Sediment Grain Size Analysis

\begin{tabular}{lllll}
\hline $\begin{array}{l}\text { Diameter } \\
\text { Sieve } \\
(\mathrm{mm}\end{array}$ & $\begin{array}{l}\text { soil } \\
\text { retained on } \\
\text { each sieve } \\
\text { (gram) }\end{array}$ & $\begin{array}{l}\text { \% soil } \\
\text { retained } \\
\text { on each } \\
\text { sieve }\end{array}$ & $\begin{array}{l}\text { soil } \\
\text { retained } \\
\text { finer }\end{array}$ & $\begin{array}{l}\text { \% } \\
\text { Finer }\end{array}$ \\
\hline 4.75 & 5.46 & 2.73 & 194.54 & 97.27 \\
2.36 & 27.14 & 13.57 & 167.40 & 83.70 \\
1.18 & 39.14 & 19.57 & 128.26 & 64.13 \\
0.6 & 60.68 & 30.34 & 67.58 & 33.79 \\
0.3 & 47.49 & 23.74 & 20.09 & 10.05 \\
0.15 & 17.57 & 8.78 & 2.53 & 1.26 \\
0.075 & 2.53 & 1.26 & 0.00 & 0.00 \\
\hline
\end{tabular}

The average value of the sediment grain size for $\mathrm{D}_{50}$ was found to be $0.91 \mathrm{~mm}$ while $\mathrm{D}_{95}$ was $4.35 \mathrm{~mm}$.

\subsection{Analysis of Design Flood Discharge}

This study used the peak discharge from Synthetic Unit Hydrograph Nakayasu method to calculate the scour depth and the application of the Log Pearson Type III distribution for rainfall plan was also acceptable. Moreover, the Repeat Periode Year Design Rain and Parameter of the Krueng Seunagan River Basin is presented in Table 6.

Table 6. Repeat Periode Year Design Rain and Parameter of The Krueng Seunagan River Basin

\begin{tabular}{ll}
\hline Parameters of Nakayasu & Data and Result \\
\hline$Q_{p} 50$ & 195.130 \\
$Q_{p} 100$ & 299.230 \\
Watershed Area & $995.86 \mathrm{~km}^{2}$ \\
length of the longest channel & $132.92 \mathrm{~km}$ \\
$T_{g}=0.40+0.058 * L$ & 7.749 hours \\
$T_{p}=T_{g}+0.8 * T_{r}$ & 12.399 hours \\
$T_{r}=0.75 * \operatorname{tg}$ & 5.812 hours \\
$T_{0,3}=\alpha * T_{g}$ & 15.499 hours \\
$Q p=\frac{1}{3.6}\left(\frac{A R e}{0.3 T p+T_{0.3}}\right)$ & $14.394 \mathrm{~m}^{3} / \mathrm{det}$ \\
\hline
\end{tabular}

The longest river length for the Krueng Seunagan watershed is $132.92 \mathrm{~km}$ while the area is 995.86 $\mathrm{km}^{2}$ and unit discharge into the rain $\left(R_{50}\right)$ is $195.130 \mathrm{~mm}$ as indicated in Table 6 while the Hydrograph Nakayasu presented in Figure 5 shows the peak discharge at $Q p_{50}$ to be $1354.5 \mathrm{~m}^{3} / \mathrm{sec}$ and $Q p_{100}$ to be $1513 \mathrm{~m}^{3} / \mathrm{sec}$. 


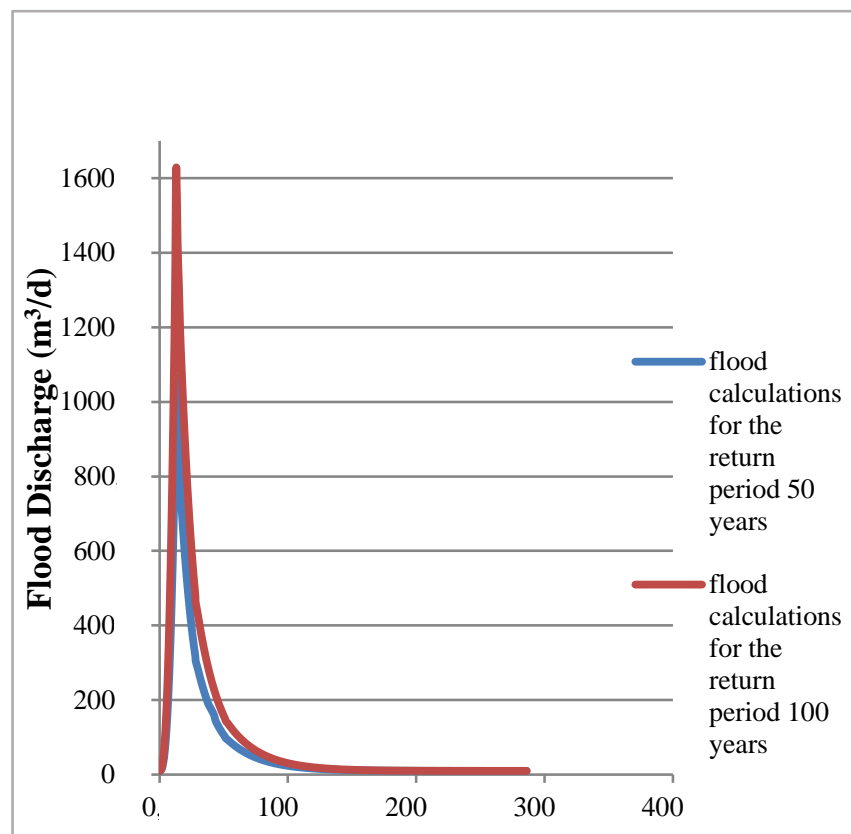

time (hours)

Figure 5. Hydrograph Nakayasu

3.4 Analysis of Scouring Depth with Empirical Method

The local scour was calculated using the Colorado State University, Froehlich, and Lacey methods, and the results are presented in the following sub-sections.

3.4.1 Local scour with the Colorado State University method:

The data obtained using this method are presented in Table 7 .

Table 7. Parameters Data for Scouring Depth Analysis using CSU Method

\begin{tabular}{ll}
\hline Parameter & Values Data \\
\hline$B$ (width of the pier) & 4.0 \\
$L$ (pier length) & 10.0 \\
$y$ (depth of flow) & 2.28 \\
$V$ (flow velocity) & 1.36 \\
$K 1$ (correction factor for pier nose shape) & 0.7 \\
$K 2$ (correction factor for the angle of attack & 0 \\
of flow) & \\
$K 3$ (correction factor for bed condition) & 1.1 \\
$D 50$ (grain size diameter) & 0.91 \\
$F R$ (Froude number) & 0.29 \\
$D 95$ (grain size diameter) & 4.35 \\
\hline
\end{tabular}

$$
\begin{aligned}
& K_{2}=\left(\cos \theta_{p}+\frac{L}{b} \sin \theta_{p}\right)^{0,65}=\left(\cos 0+\frac{10}{4} \sin 0\right)=1.0 \\
& V_{c 50}=K_{u} y_{3}{ }^{1 / 6} D_{50}{ }^{1 / 3} \\
& V_{c 50}=6.19 \times 3.06^{\wedge 1 / 6} \times 0.91^{\wedge 1 / 3}=7.228 \\
& V_{c 95}=K_{u} y_{3}{ }^{1 / 6} D_{95}{ }^{1 / 3} \\
& V_{c 95}=6.19 \times 3.06^{\wedge 1 / 6} \times 4.35^{\wedge 1 / 3}=12.175 \\
& V_{i 50}=0.645\left(\frac{D_{50}}{b}\right)^{0,053} V_{c 50} \\
& V_{i 50}=0.645 \times\left(\frac{0.91}{4}\right)^{\wedge 0.053} \times 7.228=4.31 \\
& V_{i 95}=0.645\left(\frac{D_{95}}{b}\right)^{0.053} V_{c 95} \\
& V_{i 95}=0.645 \times\left(\frac{4.35}{4}\right)^{\wedge 0.053} \times 12.1752=7.888 \\
& V_{R}=\left(\frac{V_{3}-V_{i 50}}{V_{c 50}-V_{i 95}}\right)=\left(\frac{1.36-4.31}{7.228-7.888}\right)=4.46 \\
& K_{4}=0.4\left(V_{R}\right)^{0.15}=0.4 \times 4.46^{\wedge 0.15}=0.501 \\
& d_{s}=2.0 \times K_{1} \times * K_{2} \times K_{3} \times K_{4} \times F^{0.43} \times y_{3}^{0.35} \\
& d_{s}=2.0 \times 0.7 \times 1.0 \times 1.1 \times 0.501 \times 0.29^{\wedge 0.43} \times 3.06^{\wedge} 0.35 \\
& d_{s}=2.43 m
\end{aligned}
$$

The local scour depth was, therefore, empirically found to be $2.43 \mathrm{~m}$ using the CSU method.

\subsubsection{Local scour with the Froehlich method:}

The scour depth was obtained with the Froehlich method using the following equations:

$$
\begin{gathered}
b^{\prime}=b \cos \beta+l \sin \beta=4 \times \cos 0+l \times \sin 0=4 \\
d_{s}=0.32 b K\left(\frac{b^{\prime}}{b}\right)^{\wedge 0.02}\left(\frac{y}{b}\right)^{\wedge} 0.46 \mathrm{Fr}^{\wedge 0.2}\left(\frac{b}{d_{50}}\right)^{\wedge 0.08}+1,0 \\
d_{s}=0.32 \times 4 \times 0,7 \times\left(\frac{4}{4}\right)^{\wedge 0.02} \times\left(\frac{3.06}{4}\right)^{\wedge} 0.46 \\
\times 0.288^{\wedge 0,2} \times\left(\frac{4}{0.91}\right)^{\wedge 0.08}+1.0 \\
=1.68 \mathrm{~m}
\end{gathered}
$$

The value was empirically found to be $1.68 \mathrm{~m}$.

\subsubsection{Local scour with the Lacey method:}

The scour depth was calculated with the Lacey method using the following equations.

$$
\begin{aligned}
& d_{s}=0.473\left(\frac{Q_{50}}{f}\right)^{0.33}=0.473\left(\frac{1354.5}{1.679}\right)^{0.33}=4.3 \mathrm{~m} \\
& d_{s}=0.473\left(\frac{Q_{100}}{f}\right)^{0.33}=0.473\left(\frac{1513}{1.679}\right)^{0.33}=4.47 \mathrm{~m}
\end{aligned}
$$


The local scour depth for the study area was empirically found by the Lacey method to be $4.3 \mathrm{~m}$ for $Q p_{50}$ and $4.47 \mathrm{~m}$ for $Q p_{100}$. These values were observed to be greater than those obtained from CSU and Froehlich methods due to the use of only flood discharge design without pier shape, pier dimensions, and other parameters in this method.

3.5 Analysis of the Scouring Depth around the Bridge Pier

This study focused on scour depth around the river station $\mathrm{P} 2, \mathrm{P} 3$, and $\mathrm{P} 4$ with the pier position observed to be at review points of S3, S4, S5, and S6, and the results are presented in Table 8.

Table 8. Analysis of Local Scour Depth around the Bridge Pier of the Study Area

\begin{tabular}{ccccccccc}
\hline \multirow{2}{*}{$\begin{array}{l}\text { River } \\
\text { sta }\end{array}$} & \multicolumn{3}{c}{ Froehlich } & \multicolumn{4}{c}{ Colorado State University } \\
\cline { 2 - 9 } & S3 & S4 & S5 & S6 & S3 & S4 & S5 & S6 \\
\hline P2 & 1.48 & 1.52 & 1.65 & 1.59 & 2.09 & 2.39 & 2.8 & 2.62 \\
P3 & 1.48 & 1.52 & 1.68 & 1.58 & 2.25 & 2.36 & 2.9 & 2.58 \\
P4 & 1.47 & 1.52 & 1.60 & 1.57 & 2.21 & 2.36 & 2.6 & 2.55 \\
\hline
\end{tabular}

Table 8 shows the scour depth around the bridge pier is located on river stations P2 and P3 with pier position at a review point of S5 and the maximum values were 1.65 and 1.68 meters.

\section{CONCLUSIONS}

The peak discharge in the Seunagan Krueng watershed was found to be $Q p_{50} 1354.5 \mathrm{~m}^{3} / \mathrm{sec}$ and $\mathrm{Qp}_{100} 1513 \mathrm{~m}^{3} / \mathrm{sec}$ using the HSS Nakayasu method while the average values of sediment grain size for $\mathrm{D}_{50}$ was $0.91 \mathrm{~mm}$ and $\mathrm{D}_{95}$ was $4.35 \mathrm{~mm}$. Moreover, the local scour depth was analyzed using empirical methods and the results showed $2.43 \mathrm{~m}$ for the Colorado State University (CSU), $1.68 \mathrm{~m}$ for the Froehlich, and $4.3 \mathrm{~m}$ and 4.47 for the Lacey method. It was, however, recommended that further research compare the scour depth analysis with Hecras 5.0.7 software and conduct necessary experiments in the laboratory using different piers shapes.

\section{DISCLAIMER}

The authors declare no conflict of interest.

\section{ACKNOWLEDGMENT}

The author appreciates all the lecturers and academic staff of the Teuku Umar University Faculty of Civil Engineering for allowing this research to be conducted with the hope of providing input to the city government as preliminary information on local scour conditions at the study site.

\section{REFERENCES}

Administration, Federal Highway, 2012. Evaluating Scour at Bridges (HEC-18), $5^{\text {th }}$ Edition. no. 18: 1-340.

Ahmad, Nordila, Mohammad, T. A, and Zuliziana Suif., 2017. Prediction of Local Scour around Wide Bridge Piers under Clear-Water Conditions. International Journal of GEOMATE, 12 (34), pp. 135-39.

Akan, Osman., 2006. Open Channel Hydraulics. Canada: Butterworth-Heinemann.

Breusers, HNC, and AJ Raudkivi, 1991. Scouring, Hydraulic Structures Design Manual. Rotterdam : AA Balkema.

Farooq, Rashid, and Ghumman, A.R., 2019. Impact Assessment of Pier Shape and Modifications on Scouring around Bridge Pier. Water, 11, pp. 1-21.

Froehlich, David C., 2013. Protecting Bridge Piers with Loose Rock Riprap. Journal of Applied Water Engineering and Research, 1(1), pp 39-57.

Garde, R, J, and C Kothyari, U., 1998. Scour Around Bridge Piers. Proceedings of the Indian National Science Academy.

Melville, Bruce., 2008. The Physics of Local Scour at Bridge Piers. Proceedings of the $4^{\text {th }}$ International Conference on Scour and Erosion, (1), pp. 28-40.

Piers, Bridge, I., Akib, S., and Rahman, S., 2013. Time Development of Local Scour around Semi. World Academy of Science, Engineering and Technology International Journal of Civil and Environmental Engineering, 7 (7), pp. 2221-26. 
Purwantoro, Didik., 2015. Model Pengendalian Gerusan Di Sekitar Abutmen Dengan Pemasangan Groundsill Dan Abutmen Bersayap. Inersia, 11 (1), PP. 79-89.

Rahman, MM, and MA Haque., 2003. Local Scour Estimation at Bridge Site: Modification and Application of Lacey Formula. International Journal of Sediment Research, 18 (4), pp. 333-39.

Rizaldi, Akbar, Farid, M., Moe, I.R., and Kendra, H., 2020. Study on Flow Regime Change Due to Weir Construction Plan in Batang Asai River, Sarolangun, Province of Jambi. IOP Conference Series: Earth and Environmental Science, 437 (1).
Roy, Chandan., 2017. Effect of Bridge Pier Geometry on Local Scouring. International Journal of Earth Sciences and Engineering, 10 (02), pp. 37477.

Rustiati, Bariroh, N., 2007. Gerusan Lokal Disekitar Abutment Jembatan Labuan. SMARTek 5, (3), pp. 157-65.

Yuliansyah, I, Aprizal, and A Nurhasanah. 2017. Comparative Analysis of Flood Hydrograph Way Kandis River Basin with Synthetic Units Hydrograph (HSS) Snyder, Nakayasu, and Limantara Methods. The 4th International Conference on Engineering and Technology Development (ICETD, no. Icetd: 60-69. 
[This page is intentionally left blank] 